\author{
BEATA BURSKA-RATAJCZYK \\ Uniwersytet Łódzki, Wydział Filologiczny, Instytut Filologii Polskiej, \\ Katedra Współczesnego Języka Polskiego
}

\title{
Elementy dawnego wyposażenia wojskowego a realia historyczne w powieści dla młodzieży pt. Bartek, Tatarzy i motorynka Cezarego Leżeńskiego
}

Cezary Leżeński - pisarz i dziennikarz, autor licznych powieści, opowiadań, szkiców i reportaży historycznych. Znany jest przede wszystkim jako twórca popularnych książek dla młodzieży: Jarek i Marek na tropie szpiega; Strachy z południowej wieży, czyli Filip detektywem; Bartek, Zuzanna i Kopernik. Jego utwory wygrywają konkursy czytelnicze, powieść Jarek i Marek bronia Warszawy znalazła się na liście hitów literatury młodzieżowej. Autor został uhonorowany wieloma odznaczeniami, m.in. Orderem Uśmiechu, za działalność na rzecz dzieci otrzymał obywatelstwo Nowego Orleanu w USA.

Bartek, Tatarzy $i$ motorynka to powieść dla młodzieży. Jej tytułowy bohater Bartek, uczeń szkoły podstawowej w Warszawie, jest obdarzony szczególną umiejętnością przenoszenia się w miejscu i w czasie. Wydarzenia współczesne przeplatają się $\mathrm{w}$ utworze $\mathrm{z}$ historycznymi oraz elementami fantastycznymi, a wszystko połączone jest klamrą magicznych zdarzeń. Powieść opisuje walki Polaków z Tatarami, m.in. oblężenie Nidzicy, zawiera informacje na temat bitwy pod Prostkami (8 października 1656 r.). Nidzica jest miastem położonym w województwie warmińsko-mazurskim, nad rzeką Nidą. Prawa miejskie nadali jej Krzyżacy w 1381 r., burzliwe były dzieje miasta w XV i XVI w., kiedy kolejno przechodziło pod panowanie Polaków lub Krzyżaków. Przedmieścia Nidzicy zostały spalone po bitwie pod Prostkami, w której przeciwko Szwedom, Brandenburczykom i Prusakom walczyli Polacy wspierani przez oddziały tatarskie.

Historyczne tło powieści sprawia, że autor posługuje się terminologią wojskową, czyni to świadomie, w celu dokonania archaizacji. Archaizacja jest jednym z trzech (obok stylizacji gwarowej i kolokwializacji) najczęściej stosowanych 
rodzajów stylizacji językowej. Archaizm to element języka odczuwany współcześnie jako przestarzały lub taki, który wyszedł z użycia. Wyrazy stare, średniowieczne, charakterystyczne dla minionych okresów rozwoju języka, nie należą do czynnego zasobu słownego współczesnych Polaków. Archaizm (z grec. archaismós) oznacza również formę wyrazową lub konstrukcję składniową. Przedmiotem analizy są archaizmy leksykalne stosowane w powieści w celach stylizacyjnych. Używanie archaizmów jako wykładników stylizacji archaizującej ma swój początek w literaturze romantycznej. S. Dubisz [1991: 21-23] potwierdza, że archaizacja koncentruje się na sferze tekstów artystycznych (tekstów utworów literackich) i jest zabiegiem świadomym i celowym.

Militaria są wiarygodnymi świadkami historii, dzięki nim możemy w sposób doskonalszy rekonstruować wielkie bitwy, które zmieniły dzieje narodów. Autorzy opracowań z zakresu wojskowości podkreślają, że:

Dawne militaria cieszą się niesłabnącym zainteresowaniem społeczeństwa, zwłaszcza młodzieży, co znajduje potwierdzenie w czytelnictwie odpowiedniej literatury oraz w odbiorze audycji radiowych, spektakli teatralnych, filmowych i telewizyjnych [Żygulski jun., Wielecki 1988: 6].

Wielu lingwistów koncentrowało się na badaniu i opisie słownictwa wojskowego w tekstach literackich i historycznych - bogatą dokumentację poświęconą militariom z XVII w. znajdujemy np. w opracowaniu I. Szlesińskiego [1985].

Książka Cezarego Leżeńskiego może zainteresować językową różnorodnością słownictwa wojskowego, pojawiającego się na jej kartach. Celem opracowania jest zwrócenie uwagi na leksykę wojskową i sposób jej wykorzystania w utworze literackim oraz ustalenie, czy pisarz wykorzystał terminologię wojskową zgodnie z realiami historycznymi. Niektóry twórcy z wyjątkową starannością oddają detale historyczne, inni z rozmysłem odchodzą od realiów epoki, ponieważ interpretują dzieje za pomocą swoistych metod i oryginalnego języka artystycznego.

Autor „Bartka, Tatarów i motorynki” w szerokim zakresie wprowadził do powieści słownictwo wojskowe, ale ze względu na rozmiary opracowania z utworu wyekscerpowano tylko część materiału, tj. nazwy broni zaczepnej i obronnej, pominięte zostały nazwy odnoszące się do takich obszarów wojskowości, jak np. strategia, taktyka, fortyfikacja. Poszczególne przykłady pochodzą z wydania drugiego powieści [Leżeński 1999]. Cytaty zostały wyróżnione kursywą i oznaczone numerem strony, zastosowane $\mathrm{w}$ nich podkreślenia pochodzą od autorki artykułu.

Obecność terminów wojskowych wynika z faktu, że w akcję powieści wkomponowano opisy walki Polaków z Tatarami:

Otóż w roku pańskim 1656 Tatarzy, którzy po bitwie pod Prostkami koło Grajewa, gdzie wspomagali Polaków w walce ze Szwedami, powracali w swe rodzinne strony. Jakiś czambut z wielkiej ordy zapuścit się pod Nibork [63]. 
W XVII w. Tatarzy nękali Rzeczypospolitą najazdami i grabieżami. Podstawę utrzymania Tatarów stanowiło pasterstwo, jednak, jak uzasadniają historycy wojskowości:

[...] wskutek niepomyślnych warunków klimatycznych dotykała ich często klęska głodu, która zmuszała Tatarów do wypraw rabunkowych na gęściej zaludnione i lepiej zagospodarowane ziemie Rzeczypospolitej i Rosji. [...]. W licznych najazdach na Rzeczypospolitą, których w pierwszej połowie XVII w. było co najmniej 76, rzadko uczestniczyły całe siły tatarskie; oblicza się je na 20 000-30 000 wojowników. Zwykle brały w nich udział poszczególne ordy lub pojedyncze czambuły nie przekraczające kilku tysięcy ludzi [Nowak, Wimmer 1981: 437].

Ludność wraz z dobytkiem znajdowała ochronę przed najazdem w punktach umocnionych, którymi były miasta, rezydencie magnackie, klasztory, kościoły. Takim miastem w powieści C. Leżeńskiego jest Nidzica, zwana dawniej Niborkiem.

Spośród licznie reprezentowanej w utworze leksyki wojskowej szczególną uwagę poświęcono nazwom dawnej broni. Broń towarzyszyła człowiekowi od czasów najdawniejszych, w badaniach nad jej historią wykorzystuje się źródła archeologiczne i ikonograficzne, ale także różne typy źródeł pisanych. W Leksykonie wiedzy wojskowej [1979: 51] narzędzia walki zostały podzielone na broń dawną (historyczną) i współczesną. Broń dawna obejmuje broń zaczepną, czyli broń miotającą, broń białą - sieczną, kłującą, drzewcową, obuchową i dawną broń palną, ponadto broń ochronną, czyli elementy wyposażenia walczącego, które służą do osłaniania ciała przed uderzeniem, pchnięciem, cięciem. Do broni dawnej zaliczono: proce, łuki, kusze, oszczepy, dzidy, bumerangi, machiny miotające, tarany do rozbijania murów, wieże oblężnicze; topory, miecze, szable; rusznice, arkebuzy, muszkiety, karabiny skałkowe, armaty oraz zbroje, tarcze, szyszaki, nagolenniki, hełmy.

W powieści znajdujemy bogatą dokumentację nazw broni historycznej używanej przez Polaków i Tatarów. Niektóre z nazw znane są badaczom starych tekstów, historykom, prawnikom, językoznawcom, część elementów dawnego wyposażenia wojskowego poznajemy, czytając stare lub archaizowane teksty, odwiedzając muzea, oglądając obrazy czy ryciny.

Analizowany materiał dostarcza wielu przykładów nazewnictwa broni używanej dawniej.

\section{Nazwy broni zaczepnej}

\section{Broń palna}

Definiowana jest jako 'broń mająca elementy wybuchowe'.

Sz. Kobyliński określa wiek XVII jako „zadomowiony już bronią palną” [1984: 34]. Opracowania wojskowe podają, że w sprzęcie artylerii w drugiej 
połowie XVII w. przybywało dział żelaznych, większych i mniejszych, część z nich stanowiły działa zdobyczne. W. Zawadzki pisze, że po sukcesie polskiej husarii w bitwie pod Kircholmem (27 września 1605 r.) ,zwycięscy wzięli wszystkie 11 armat szwedzkich" [2006: 6].

W powieści czytamy, że jedynym sposobem uratowania Nidzicy było pokonanie oblegających ją Tatarów. Wiedziano, że miasto nie może wytrzymać dłuższego oblężenia ze względu na kruchość umocnień i słabość załogi. Mieszkańcy grodu bronili się, używając armat $\mathrm{i}$ hakownic, które dawały walczącym wsparcie ogniowe, np.

Mała armata jest tylko na wieży zamku [...] [151].

Jak podaje słownik języka polskiego, armata to 'broń artyleryjska o długiej lufie, odznaczająca się dużą donośnością i dużą prędkością pocisku, przy płaskim torze jego lotu; stosowana w walce naziemnej, morskiej i powietrznej; działo' z łc. [SJPS, t. 1: 79].

Warto też zwrócić uwagę na występującą w utworze nazwę hakownica, np.

Z blanków posypały się wystrzaty muszkietów, pistoletów, a nawet odezwała się hakownica [157].

Hakownica to pewien rodzaj armatki, w opracowaniu słownikowym czytamy: hakownica hist. 'długa strzelba z hakiem służącym do podpierania jej przy strzale lub zaczepienia o blanki murów, używana w XV-XVII w.' [SJPS, t. 1: 720], natomiast publikacje z zakresu bronioznawstwa zaliczają hakownice oraz śmigownice do rodzaju armatek lekkich [por. Wimmer 1972: 181] i wyjaśniają, że hakownice określane także jako duże strzelby wałowe, montowane były również na wozach, aby zwiększyć siłę ogniową, wykorzystywano je „nie tylko w walkach z Tatarami, ale również w czasie wojny ze Szwecją [...]" [Nowak, Wimmer 1981: 423].

Nazwa hakownica może być dla wielu czytelników niejasna, ale zawarty w powieści dokładny opis trafnie oddaje budowę i funkcję tego rodzaju broni palnej:

Niesiono wydobyte gdzieś ze zbrojowni niewielkie hakownice, czyli mate armatki bez kót, za to z hakiem stużacym do zaczepiania o mur w taki sposób, aby zabezpieczyć broń przed odrzutem po strzale.

- Jest hakownica.

W kacie stało coś niewiele większego od muszkietu, z solidna dẹbowa kolba $i$ charakterystycznym hakiem [184].

Bardzo szczegółowy opis hakownicy podaje Sz. Kobyliński „Broń ma rozmiary późniejszego pistoletu, kształt armaty, a nosi się ją jak karabin - w drewnianym łożu z kolbą. [...] W miarę potężnienia wybuchu i zwiększenia broni, szczególnie fortecznej, dorobiono u spodu całości specjalny krzepki hak, który podczas akcji zaczepiano o krawędź muru, belkę obwarowań lub wycięcie w tarczy [...]. Stąd też i określenie broni - hakownica. „Lżejsze okazy przykładano do ramienia”, „hakownica biła skutecznie na dziesiątki metrów” [1984: 22]. 
Kolejnym narzędziem walki wymienionym w powieści jest muszkiet:

Z blanków posypały się wystrzały muszkietów [...] [157].

Tatarzy rzeczywiście mało nie wdarli się do miasta. Pięli się na mury po przystawionych drabinach. Odpychano je dragami, strzelano z muszkietów wprost w twarze atakujacych [178].

- Przecież dosyć u nas muszkietów $i$ hakownic - zauważyt Bartek - a oni maja tylko tuki $i$ strzaty [179].

W słowniku języka polskiego czytamy: muszkiet hist. 'ręczna broń palna lontowa o lufie gładkiej, dużego kalibru, używana przez piechotę w XVI-XVII w.' z fr. [SJPS, t. 2: 231]. Jak podają opracowania historyków uzbrojenia w wojsku stosowano dwa rodzaje muszkietów: lontowe wzoru holenderskiego, które wprowadził Gustaw Adolf i muszkiety z zamkiem kołowym [Nowak, Wimmer 1981: 392].

Koło Bramy Polskiej ruch panowat jak nigdy. Na blanki spieszyli mieszczanie, niosacy stare pordzewiałe szable, archaiczne muszkiety na lont [...] [189].

Od początku starano się o ulepszenie muszkietów o długich rurach i udoskonalenie sposobu odpalania pocisku. Muszkiety na lont zostały w powieści określone jako archaiczne, ponieważ, jak wyjaśnia Sz. Kobyliński, w XVII wieku: „Wchodzą bowiem w coraz powszechniejsze użycie zamki kołowe. Specjalnym kluczem wojak nakręca sprężynę metalowego kółka z boku zamka i - nabiwszy broń od przodu prochem, pakułami i odpowiednią kulą lub „siekańcami” dla większego rażenia - czeka odpowiedniej chwili" [1984: 28]. O muszkietach z zamkiem kołowym czytamy: „Były one przydatne w nocy, bo nie zdradzały żołnierza ogniem tlącego się lontu" [Nowak, Wimmer 1981: 392], ponadto okazały się bardziej efektywne, ponieważ zapewniały większą szybkostrzelność, i bardziej niezawodne, bo odporne na złe warunki klimatyczne, np. deszcz [por. Adam 1992: 6].

Muszkiety używane były także do wystrzałów z okazji uroczystości. Mieszkańcy Nidzicy wystrzałami z broni świętowali zwycięstwo nad Tatarami:

Ze środka grodu dobiegaty wesołe okrzyki, radosny gwar, a czasem wystrzat $z$ muszkietu [194].

Wśród nazw broni palnej w powieści pojawia się pistolet.

Z blanków posypały się wystrzały muszkietów, pistoletów [...] [157].

Pistolet to 'krótka broń palna, przeznaczona do strzelania z ręki na bliskie odległości amunicją o energii mniejszej niż w amunicji karabinowej’ z fr. [SJPS, t. 2: 679]. Nazwa funkcjonuje w polszczyźnie współczesnej, choć zdecydowanie zmienił się wygląd broni. R. Adam wyjaśnia, że: „Pistolety z XVI i XVII wieku - zwane wówczas powszechnie „krótkimi rurkami” - to konstrukcje jednolufowe [...]" [1992: 6]. Były one na wyposażeniu wojska, gdy husarzy „wyruszali przeciw Tatarom; zabierali wówczas silne uzbrojenie strzeleckie w postaci muszkietu i pistoletów" [Nowak, Wimmer 1981: 478]. 


\section{Broń biała}

Kolejnym stosowanym rodzajem broni, która pojawia się na kartach powieści, jest broń biała w Nowej encyklopedii powszechnej PWN definiowana jako 'broń nie mająca elementów wybuchowych, od najdawniejszych czasów do XVI w. była podstawową bronią używaną do walki wręcz, rozróżnia się broń obuchową (maczuga, topór), broń drzewcową (oszczep, włócznia, pika), broń sieczną (szabla, szpada, miecz)' $[1995$, t. 1: 570].

\section{Broń drzewcowa}

Do broni drzewcowej zalicza się halabardę.

$W$ progu stanęli mężczyźni w metalowych hetmach $i$ z halabardami w ręku [118].

Cóż mu mogli zrobić ci ludzie ze śmiesznymi halabardami? [119].

Halabarda obecnie używana w gwardii papieskiej, to 'śrdw. broń piechoty, złożona z siekiery, grotu i haka, osadzona na długim drzewcu, od XVII w. używana przez straż miejską i dworską (halabardników)'. Nm. Hellebarde z śr.g.nm. helmbarte 'topór z długim toporzyskiem (styliskiem)'; helm 'rękojeść', barte 'topór' ze st.g.nm. bart 'broda' [K, t. 4: 225].

Występuje też w utworze nazwa rohatyna.

Koło Bramy Polskiej ruch panowat jak nigdy. Na blanki spieszyli mieszczanie, niosacy stare pordzewiate szable, archaiczne muszkiety na lont [...], a nawet rohatyny [189].

Rohatyna hist. 'włócznia z hakiem przy grocie używana w XVI i XVII wieku przez lekką jazdę oraz w dawnym myślistwie' $\mathrm{z}$ ukr. [SJPS, t. 3: 69].

W powieści charakterystycznym elementem uzbrojenia Tatarów są dzidy, dziryty i piki.

W ręku trzymali krótkie dzidy [143].

- Widziatem, jak takie dzidy opieraja o namiot, kiedy wchodza do środka [153].

W dalszej częśsi obozowiska ktębit się ttum kobiet, dzieci, a nawet mężczyzn, których pilnowali wojownicy z dzidami [148].

Wyprowadze cię teraz jako niewolnika. Trzymaj ręce do tylu tak, jakbyś byt zwiazany. Dobrze, żebym miat dzide, wtedy nikt by się nie domyślit [152].

Dzida 'dawna broń składająca się ze strzałkowatego ostrza osadzonego na dhugim drzewcu' [SJPS, t. 1: 497].

- Zrzucaj to, ale prędko! - Bartek prasnąt dzirytem o pień drzewa [157].

Dziryt 'rodzaj włóczni o krótkim drzewcu i wąskim grocie używanej powszechnie od najdawniejszych czasów jako broń myśliwska i wojenna do wal- 
ki wręcz lub na odległość; dziś używana przez niektóre plemiona afrykańskie' [SJPS, t. 1: 508].

Wśród nazw broni występuje także pika.

[...] wyszło dwóch wojowników z pikami w dłoniach i łukami zawieszonymi $z$ boku [...] [151].

Warto dodać, że pika hist. 'broń używana w Europie od XV do początku XVIII wieku przez piechotę, składająca się z długiego drzewca i małego ostrego grotu’ z fr. [SJPS, t. 2: 667]. Zwłaszcza długie piki służyły do zastawiania się przed nacierającą konnicą nieprzyjaciela. Jak wyjaśniają historycy wojskowości ,[...] z wyjątkiem nielicznych oddziałów piechoty typu polskiego, wszystkie jednostki składały się w $2 / 3$ z muszkietów, $\mathrm{w} 1 / 3 \mathrm{z}$ pikinierów, uzbrojonych poza zasadniczą bronią w szable" [Wimmer 1972: 168].

\section{Broń obuchowa}

W obronie grodu przed Tatarami stanęli nie tylko żołnierze, ale także zastępy drobnej szlachty, mieszczan i włościan, stąd różne narzędzia walki. Używano także broni obuchowej, np. toporów.

Bramy byly już starannie zaryglowane, a na blankach stali mieszkańcy, trzymając w rękach muszkiety, szable, topory [...] [137].

Topór to narzędzie rażenia z bliska '[...] składające się ze stalowego żeleźca o szerokim ostrzu, osadzonego na drewnianym trzonku, używane do ścinania, rąbania czegoś, dawniej też jako broń obuchowa' [SJPS, t. 3: 514].

\section{Broń sieczna}

W powieści wojownicy używają także broni siecznej. Obrońcy Nidzicy mają szable i szpady.

Koło Bramy Polskiej ruch panowat jak nigdy. Na blanki spieszyli mieszczanie, niosacy stare pordzewiate szable, archaiczne muszkiety na lont [...] [189].

Jak wyjaśnia Sz. Kobyliński szabla: „Przyszła ze Wschodu” i okazała się bardziej uniwersalna niż miecz czy rapier [1984: 26]. Szabla definiowana jest w słowniku jako 'broń sieczna o wygiętej jednosiecznej klindze (dziś używana tylko jako broń sportowa)' [SJPS, t. 3: 388]. W opracowaniach z zakresu wojskowości czytamy: „W kawalerii w drugiej połowie XVII i z początkiem XVIII w. [...] uzbrojenie zaczepne na zachodzie Europy stanowiła szabla lub pałasz oraz pistolety" [Nowak, Wimmer 1981: 456]. Poza tym piechota polsko-węgierska uzbrojona była w rusznice, szable, siekierki [por. Nowak, Wimmer 1981: 478].

Obok szabli używana jest także szpada.

Porwat się Sparry z lawy i za szpade chciat chwycić, ale od razu zreflektowat się $[\ldots][136]$.

M. Szymczak tak definiuje hasło szpada 'dawna broń sieczna o prostej i ostro zakończonej głowni; dziś broń sportowa używana w szermierce’ $\mathrm{z}$ wł. [SJPS, t. 3: 422]. 
Opis dawnej broni w powieści zawiera informacje, że była ona nie tylko narzędziem walki, ale często także obiektem kunsztownego rzemiosła artystycznego:

[...] i nie watpim, żeś także poddanym najmiłościwszego króla Jana Kazimierza, od którego sam Subchan Ghazi, wódz czambułów tatarskich, otrzymat złota karabele gesto wysadzana turkusami [...] [163].

Karabela hist. 'lekka, ozdobna szabla z otwartym jelcem i głowicą rękojeści w kształcie głowy orła, noszona przez szlachtę polską, głównie do paradnego stroju' «może od nazwy miasta albo od nazwiska płatnerza» [SJPS, t. 1: 881].

Kolejny rodzaj broni siecznej stanowi rapier.

Byt to mężczyzna wysoki, prawie chudy, ubrany w brazowy skórzany kaftan, wysokie buty rajtarów szwedzkich, szeroki kapelusz z piórami, a przy pasie dyndat mu rapier [3-4].

Rapier 'broń sieczna o klindze długiej, prostej obosiecznej i koszowej gardzie (XVI-XVII w.), fr. rapière od rápier 'trzeć na tarce', którą przypominała wyglądem, dziurkowana a. koszowa garda rapiera' [K, t. 5: 113].

\section{Broń miotająca}

Istotnym elementem uzbrojenia wojowników tatarskich były luki.

- Tam do paralusza! Szyja z tuków beskurcyje jedne [145].

W odległości prawie stu metrów grupka Tatarów opuszczała powyginane fantazyjnie tuki [145].

[...] wyszło dwóch wojowników z pikami $w$ dłoniach i łukami zawieszonymi z boku [...] [151].

Luk 'broń wyrzucająca strzały, składająca się z wygiętego pręta i cięciwy łączącej jego końce’ [SJPS, t. 2: 79].

\section{Nazwy części broni oraz elementów służących do jej przechowywania}

Powieść dostarcza także przykładów fachowych nazw różnych części broni siecznej i miotającej.

Część broni siecznej stanowi garda.

Porwat się Sparry z ławy i za szpadę chciat chwycić, ale od razu zreflektowat się, tylko dłonia w garde broni uderzyt i zmienionym złościa głosem wydusit:

- Despekt mi tu wasz więzień czyni, a waszmość, burmistrzu, nic na to nie mówisz [136]. 
Garda 'wypukła część rękojeści broni siecznej, ochraniająca dłoń i przegub szermierza; jelec' z fr. [SJPS, t. 1: 631].

Nieodzownym elementem uzbrojenia Tatarów są łuki i kołczany.

[...] $w$ takiej samej spiczastej czapce $z$ tukiem $i$ kotczanem petnym strzat, tkwit konny Tatar trzymający buńczuk, znak władzy, zakończony złotym, błyskajacym w stońcu pótksiężycem [143].

Kołczan 'pochwa na strzały do łuku, zwykle skórzana lub drewniana, obciągnięta skórą albo tkaniną, noszona na pasku przez ramię, u pasa lub przytwierdzona przy siodle; używana w Polsce do XVIII w.' z tur. [SJPS, t. 1: 964].

\section{Nazwy pocisków}

Wśród nazw pocisków armatnich w wyrażeniu wykrzyknikowym o charakterze przekleństwa pojawia się kartacz.

Tfu, do kroćset fur beczek kartaczy, jak mawiat Kacper, co się dzieje? [4].

$\mathrm{W}$ działaniach bojowych artylerii istotne znaczenie miało zastosowanie odpowiednich środków wybuchowych oraz właściwego typu pocisków.

Kartacz hist. 'pocisk armatni wypełniony żelaznymi kulkami lub siekańcami', 'kulki, siekańce wypełniające te pociski' z nm. [SJPS, t. 1: 891].

Jak wyjaśniają historycy wojskowości: „Z dział strzelano kulami burzącymi, granatami i kartaczami, to jest rozrywającymi się pociskami” [Nowak, Wimmer 1981: 446]. Badacze wskazują, że w wieku XVII sprzęt artyleryjski „był bardzo różnorodny; obok dział odlewanych w Polsce w różnych okresach występowały liczne armaty i moździerze zdobyczne. Utrudniało to ogromnie zaopatrywanie ich w pociski. Przykładem może być bitwa pod Gniewem, w czasie której nie wykorzystano dział, gdyż nadesłane kule nie pasowały do nich" [Nowak, Wimmer 1981: 422].

Bronią Tatarów były łuki, z których wypuszczali w kierunku obrońców strzały.

Wypuszczali przy tym strzaty, które bądź trafiały stojących na blankach, badź kazaly im schylać się nisko [177].

Niektórzy wkładali końce strzał owiniętych jakąś łatwopalna materia do saganów z żarem $i$ wystrzeliwali je w kierunku Nidzicy [192].

Strzala "pocisk wystrzeliwany z łuku, kuszy itp., składający się z pręta (drzewca) zakończonego z jednej strony ostrzem (grotem), a z drugiej zwykle piórami sterującymi (lotkami), zapewniającymi pociskowi stabilność lotu' [SJPS, t. 3: 354]. 


\section{Uzbrojenie ochronne}

Uzbrojenie ochronne opisane w powieści obejmuje różne części ciała walczących. C. Leżeński w następujący sposób przedstawia obrońców Nidzicy.

Zdumiewaty go nieco zardzewiate zbroje i hetmy, które założyli obrońcy, a rozśmieszaty ich marsowe miny niepasujace zupetnie do dobrodusznych twarzy, wielkich brzuchów badź zaokrąglonych postaci, bardziej nawyktych do stania za ladą lub szynkwasem niż do trudów wojny lub walki [137].

Zbroja występuje „w różnych kręgach kulturowych już w III milenium p.n.e., uważać ją trzeba za rodzaj ubioru wojskowego [...]" [Żygulski jun., Wielecki 1988: 7]. Sz. Kobyliński wskazuje, że „[...] przejście z wieku XVI w XVII oznacza [...] proces ewolucji wojskowego rynsztunku". Odchodzi się w miarę rozwoju broni palnej od elementów kunsztownej, pełnej zbroi, używając tylko jej elementów kolczugi. Zmieniły się bowiem sposoby wojowania, zwiększyła ruchliwość formacji wojskowych, co wymagało zastosowania „lżejszych i obrotniejszych elementów wyposażenia wojskowego" [1984: 28].

W kolczugach występują w powieści wojownicy tatarscy.

$W$ spiczastej czapce na glowie, przybrany $w$ kolczuge wykonana $z$ drutu. Na nia miat narzucony bogato haftowany kaftan [143].

Tatarzy siedzacy i chodzacy między ogniskami nie mieli przy sobie broni, zdjęli też kolczugi [148].

W słowniku języka polskiego czytamy kolczuga hist. 'rodzaj średniowiecznego pancerza rycerskiego okrywającego tułów lub całe ciało, zrobionego z drucianej siatki lub metalowych kółek' [SJPS, t. 1: 954]. Z. Żygulski jun. wyjaśnia, że: „Pancerz kolczy lub płytkowo-kolczy stanowi tradycyjną zbroję turecką, wspólną z innymi narodami wschodnimi” [1986: 31]. Jak podaje [Teodorczyk 1972: 181] wojownicy osłaniali ciało zbroją lżejszą pancerzami kolczymi (kolczugami). Dotrwały one do początków XVIII w., bardzo dokładnie opisuje ten rodzaj zbroi płytkowej Sz. Kobyliński: „Wykonują ją na Wschodzie, zwłaszcza w Azji Mniejszej, spece tak mistrzowscy i pracowici, że zdarzały się okazy kaftanów kolczych, wymagające pracy całego życia. Bo też pomyśleć: tysiące kółeczek o średnicy około 1 centymetra, które nie tylko przeplatano kunsztownie, ale i nitowano mikroskopijnymi ćwieczkami, często dubeltowo" [1984: 22].

Do osłony ciała służył znamienitym wojownikom żupan.

- Aga Subchan Ghazi jest silnym, barczystym mężczyzna w trawiastym, jedwabnym żupanie, twarz ma śniada, okolona szeroka, okragła broda, oczy mate, blyszczace, glos tagodny i nie bez wdzięku oblicze [95].

Osoby, które piastowały najwyższe funkcje i szarże wojskowe, od hetmańskich poczynając, nosiły żupany. Żupany, podobnie jak broń, stanowiły obiekt kunsztownych zdobień. Słownik języka polskiego podaje jedynie następującą 
informację: żupan 'staropolski ubiór męski o kroju długiej sukni zapinanej na haftki, guzy lub szamerowanej, ze stojącym kołnierzykiem i wąskimi rękawami, noszony przez szlachtę od XVI w. do około połowy XIX w.' z wł. [SJPS, t. 3: 1095]. Należy dodać, że żupany stanowiły także rodzaj miękkiej zbroi, rozpowszechniły się za pośrednictwem Tatarów na Rusi, w Moskwie i w Polsce. Jedwabny żupan bojowy posiadał Stefan Żółkiewski hetman wielki koronny. Ten rodzaj zbroi pochodzi z pierwszego dwudziestolecia XVII w. [Żygulski jun., Wielecki 1988: 321]. Ponadto przyjęly się w Polsce ,żupany watowe [...], używane zwłaszcza, ze względu na wysoką cenę, przez dowódców wojskowych" [Żygulski jun., Wielecki 1988: 23].

Istotnym elementem uzbrojenia ochronnego był helm.

W progu stanęli mężczyźni w metalowych hetmach i z halabardami $w$ ręku [118].

Helm to 'ochronne nakrycie głowy (dawniej też twarzy), zwykle z metalu, twardej skóry, [...] używane przez żołnierzy [...]' z nm. [SJPS, t. 1: 733]. Jak wyjaśniają historycy munduru nakrycie głowy było szczególnie ważne:

[...] zarówno z uwagi na konieczność ochrony tej części ludzkiego ciała, jak i na jej eksponowanie i widoczność z dużej nawet odległości. Wcześnie więc nauczono się przystrajać hełmy w odpowiednie znaki, grzebienie, pióropusze i kity, rogi, wreszcie symbole zwierząt, ptaków lub bóstw. Symbolika hełmu, a czasem po prostu jego kształty, decydowały o rozróżnieniu wojsk na polu bitwy, ułatwiały dowodzenie, wreszcie pozwalały uniknąć najgorszego: zabicia towarzysza broni zamiast przeciwnika [Żygulski jun., Wielecki 1988: 8].

\section{Wnioski}

Słownictwo wojskowe, które zostało (w znacznym stopniu) wprowadzone do analizowanej powieści, posłużyło pisarzowi do zachowania realizmu opisywanej epoki. Leksyka militarna przybliża młodemu odbiorcy historyczne realia, pokazuje dawny sposób prowadzenia walki, ale także życie i obyczaje ludzi tamtych czasów. Uświadamia czytelnikom rozwój oręża, zmiany narzędzi i sposobów prowadzenia działań wojennych. Wiele z użytych w powieści terminów wojskowych opatrzonych jest w opracowaniach leksykograficznych kwalifikatorem historyczny: hakownica, karabela, kartacz, kolczuga, muszkiet, rohatyna. Terminologia związana z bronią jest istotnym elementem archaizacji, oryginalne, przykuwające uwagę środki wyrazu wydobywają wiele ciekawych szczegółów historycznych, nadają tekstowi podniosły wydźwięk, umożliwiają odtworzenie kolorytu minionych epok, budują nastrój i klimat oraz tworzą barwny wizerunek żołnierza siedemnastowiecznej armii polskiej, o którym Sz. Kobyliński pisał: 
Doskonale wyćwiczony kawaleryjsko, dysponujący tak łuczniczym, jak prochowym sposobem rażenia na odległość, bił z bliska najpierw ostrą włócznią, potem zręczną szablą. A osłaniała go gruba kolczuga [...] [1984: 36].

Bogactwo leksyki wojskowej, z jaką mamy do czynienia w powieści C. Leżeńskiego, nie sprawia czytelnikowi trudności w odbiorze tekstu. Miarą wyczucia językowego pisarza jest świadomość możliwości percepcyjnych młodego czytelnika, słownictwo wojskowe autor wprowadza do powieści w taki sposób, by zachować autentyzm i pomóc młodym odbiorcom zrozumieć dawne realia. Pisarz dokładnie opisuje rynsztunek, nie pomija detali i szczegółów, pokazuje przeszłość zgodnie z rozwojem uzbrojenia w całym swym bogactwie form.

Akcja powieści jest żywa, wartka, pożytek zaś z lektury wieloraki, bowiem nie ogranicza się jedynie do zdobycia rzetelnej wiedzy o militariach tak odległej epoki, ale obrazuje także oddziaływanie języków obcych na kształtowanie się polskiego słownictwa wojskowego. Wpływy obce w tej warstwie leksyki trwały całe stulecia i pozostawiły wyraźny ślad w składzie słownictwa wojskowego, sporą grupę analizowanych nazw stanowią wyrazy zapożyczone z języka niemieckiego: halabarda, helm, kartacz. Historycy uzbrojenia wskazują, że na umacnianie tego języka w XVII w. miał wpływ „skład kadry dowódczej złożonej częściowo z Niemców, częściowo z Polaków, którzy służyli poprzednio w Niemczech w czasie wojny trzydziestoletniej [...]. Odtąd język ten długo utrzymywał się w oddziałach piechoty i dragonii, mimo prób zastąpienia go językiem polskim" [Nowak, Wimmer 1981: 421]. Znajdujemy też w słownictwie wojskowym zapożyczenia z języka francuskiego: muszkiet, pika, pistolet, rapier, tureckiego: dzida, dziryt, kołczan, włoskiego: szpada, żupan, ukraińskiego: rohatyna, czy łaciny: armata, są wśród nich zapożyczenia bezpośrednie i pośrednie, niekiedy nazwy przejęte z języków krajów dalekich: turecki, arabski.

Przeprowadzona obserwacja leksyki dowodzi, że wiele dawnych wyrazów, będących określeniami broni, wyszło z użycia. Do zaniku tych jednostek przyczyniły się przemiany cywilizacyjne. Nazwy uzbrojenia zmieniają się wraz ze sposobem prowadzenia walki. Tylko niektóre nazwy przetrwały i są obecne we współczesnej polszczyźnie, np.: pistolet, szpada, helm.

Uwagi porządkujące należy zakończyć stwierdzeniem, że polska leksyka wojskowa z XVII w. obrazuje proces mieszania się wpływów różnych, czasem bardzo odległych kultur i języków.

\section{Wykaz skrótów}

$\begin{array}{lllll}\text { ar. } & - \text { arabski } & \text { fr. } & - & \text { francuski } \\ g . & - \text { górny } & \text { hist. } & - & \text { historia, historyczny } \\ \text { tc. } & - \text { taciński } & \text { nm. } & - & \text { niemiecki }\end{array}$




$\begin{array}{lllll}o s m . & - \text { osmańsko-turecki } & s t . & - & \text { stary } \\ s ́ r d w . & - \text { średniowieczny } & \text { tur. } & - & \text { turecki(e) } \\ u k r . & - \text { ukraiński } & w t . & - & \text { włoski }\end{array}$

\section{Wykaz skrótów cytowanych źródeł}

[K] - Stownik wyrazów obcych i zwrotów obcojęzycznych, t. 4-5, W. Kopaliński (red.), Warszawa 2007 [SJPS] - Stownik języka polskiego, t. 1-3, M. Szymczak (red.), Warszawa 1978-1981

\section{Bibliografia}

\section{Źródło materiału}

Leżeński C. [1999], Bartek, Tatarzy i motorynka, Wydawnictwo Graffiti BC, Toruń.

\section{Literatura przedmiotu}

Adam R. [1992], Kolty, rewolwery i pistolety. Wspótczesna krótka broń palna, Agencja ELIPSA, Warszawa.

Dubisz S. [1991], Archaizacja w XX-wiecznej polskiej powieści historycznej o średniowieczu, Wydawnictwo Uniwersytetu Warszawskiego, Warszawa.

Kobyliński Sz. [1984], Szymona Kobylińskiego gawędy o broni i mundurze, Wydawnictwo Ministerstwa Obrony Narodowej, Warszawa.

Majewski W. [1972], Polska sztuka wojenna $w$ drugiej połowie XVII wieku, [w:] W. Biegański, P. Stawecki, J. Wojtasik (red. nauk.), Historia wojskowości polskiej. Wybrane zagadnienia, Wydawnictwo Ministerstwa Obrony Narodowej, Warszawa, s. 194-212.

Marciniak S. [1987], Język wojskowy, Wydawnictwo Ministerstwa Obrony Narodowej, Warszawa.

Nowak T. M., Wimmer J. [1981], Historia oręża polskiego 963-1795, Biblioteka Wiedzy Historycznej, Warszawa.

Szlesiński I. [1985], Słownictwo wojskowe w wybranych tekstach literackich i historycznych XVII w., Wydawnictwo Ossolineum, Wrocław.

Teodorczyk J. [1972], Wojskowość polska w pierwszej połowie XVII wieku, [w:] W. Biegański, P. Stawecki, J. Wojtasik (red. nauk.), Historia wojskowości polskiej. Wybrane zagadnienia, Wydawnictwo Ministerstwa Obrony Narodowej, Warszawa, s. 177-193.

Wimmer J. [1972], Piechota $w$ wojsku polskim XV-XVIII wieku, [w:] W. Biegański, P. Stawecki, J. Wojtasik (red. nauk.), Historia wojskowości polskiej. Wybrane zagadnienia, Wydawnictwo Ministerstwa Obrony Narodowej, Warszawa, s. 161-176.

Zawadzki W. [2006], Piechota strzelająca, ,Świat Inflant”, nr 8 (34), s. 6-7.

Żygulski Z. jun. [1986], Broń wschodnia. Turcja, Persja, Indie, Japonia, Krajowa Agencja Wydawnicza, Warszawa. 
Żygulski Z. jun., Wielecki H. [1988], Polski mundur wojskowy, Krajowa Agencja Wydawnicza, Kraków.

\section{Encyklopedie, leksykony, słowniki}

Kopaliński W. (red.) [2007], Słownik wyrazów obcych i zwrotów obcojęzycznych, t. 4-5, Wydawnictwo Naukowe PWN, Warszawa.

Laprus M. (red.) [1979], Leksykon wiedzy wojskowej, Wydawnictwo Ministerstwa Obrony Narodowej, Warszawa.

Nowa encyklopedia powszechna PWN [1995], Warszawa.

Szymczak M. (red.) [1978-1981], Słownik języka polskiego, t. 1-3, PWN, Warszawa. 